\title{
High-throughput investigation of molecular and cellular biomarkers in NMOSD
}

Soumya S. Yandamuri, MSE, PhD, Ruoyi Jiang, MS, Aditi Sharma, MBBS, Elizabeth Cotzomi, BS, Chrysoula Zografou, PhD, Anthony K. Ma, MS, Jessica S. Alvey, MS, Lawrence J. Cook, PhD, Terry J. Smith, MD, Michael R. Yeaman, PhD, and Kevin C. O'Connor, PhD, On behalf of the Guthy-Jackson Charitable Foundation CIRCLES Study Group

Neurol Neuroimmunol Neuroinflamm 2020;7:e852. doi:10.1212/NXI.0000000000000852

\section{Abstract \\ Objective}

To identify candidate biomarkers associated with neuromyelitis optica spectrum disorder (NMOSD) using high-throughput technologies that broadly assay the concentrations of serum analytes and frequencies of immune cell subsets.

\section{Methods}

Sera, peripheral blood mononuclear cells (PBMCs), and matched clinical data from participants with NMOSD and healthy controls (HCs) were obtained from the Collaborative International Research in Clinical and Longitudinal Experience Study NMOSD biorepository. Flow cytometry panels were used to measure the frequencies of 39 T-cell, B-cell, regulatory T-cell, monocyte, natural killer (NK) cell, and dendritic cell subsets in unstimulated PBMCs. In parallel, multiplex proteomics assays were used to measure 46 serum cytokines and chemokines in 2 independent NMOSD and HC cohorts. Multivariable regression models were used to assess molecular and cellular profiles in NMOSD compared with HC.

\section{Results}

NMOSD samples had a lower frequency of $\mathrm{CD} 16^{+} \mathrm{CD} 56^{+} \mathrm{NK}$ cells. Both serum cohorts and multivariable logistic regression revealed increased levels of B-cell activating factor associated with NMOSD. Interleukin 6, CCL22, and CCL3 were also elevated in 1 NMOSD cohort of the 2 analyzed. Multivariable linear regression of serum analyte levels revealed a correlation between CX3CL1 (fractalkine) levels and the number of days since most recent disease relapse.

\section{Conclusions}

Integrative analyses of cytokines, chemokines, and immune cells in participants with NMOSD and HCs provide congruence with previously identified biomarkers of NMOSD and highlight $\mathrm{CD}_{16}{ }^{+} \mathrm{CD}_{56}{ }^{+} \mathrm{NK}$ cells and CX3CL1 as potential novel biomarker candidates.

\author{
Correspondence \\ Dr. O'Connor \\ kevin.oconnor@yale.edu
}




\section{Glossary}

AQP4 = aquaporin-4; ARR = annual relapse rate; $\mathbf{A U C}=$ area under the curve; $\mathbf{B A F F}=\mathrm{B}$-cell activating factor; CIRCLES = Collaborative International Research in Clinical and Longitudinal Experience Study; HC = healthy control; IgG = immunoglobulin G; IL = interleukin; $\mathbf{M O G}=$ myelin oligodendrocyte glycoprotein; $\mathbf{N K}=$ natural killer; NMOSD = neuromyelitis optica spectrum disorder; $\mathbf{P B M C}=$ peripheral blood mononuclear cell; $\mathbf{R O C}=$ receiver operating characteristic.

Neuromyelitis optica spectrum disorder (NMOSD) is a rare autoimmune demyelinating disease of the optic nerve and spinal cord. ${ }^{1,2}$ Autoantibodies directed at the aquaporin- 4 water channel (AQP4), expressed on astrocytes in the CNS, have been identified as key contributors to NMOSD pathogenesis and are called AQP4 immunoglobulin G (IgG).$^{3-7}$ Approximately $70 \%$ of patients with NMOSD are seropositive for AQP4-IgG, which appear to contribute to disease by causing internalization of AQP4 and complement fixation. ${ }^{8-10}$ Twenty to $50 \%$ of patients in whom AQP4-IgG cannot be detected are seropositive for myelin oligodendrocyte glycoprotein (MOG) autoantibodies (MOG$\mathrm{IgG}){ }^{11-13}$ The remainder of NMOSD patients appear to be seronegative for both AQP4-IgG and MOG-IgG. Neither autoantibody has been convincingly demonstrated to predict relapse, response to therapy, or prognosis. ${ }^{14-18}$ Given the cumulative and potentially devastating nature of relapses, a prognostic biomarker would be especially valuable to herald imminent relapses and guide treatment interventions. Moreover, specific biomarkers may reveal disease mechanisms, inform disease status, provide insight for development of therapies, and help monitor treatment efficacy.

Biomarker discovery in NMOSD is hampered by disease rarity. Furthermore, studies often use an a priori single-candidate approach to biomarker discovery, limiting the probability of discovery of a potential novel biomarker. Although imaging techniques and interrogation of CSF may provide more direct information on CNS disease, the collection of blood samples is less invasive, time intensive, and costly. Therefore, we sought to perform an unbiased, discovery-based evaluation of candidate biomarkers that can be accessed from peripheral blood samples. To this end, we acquired peripheral blood mononuclear cells (PBMCs), serum, and clinical data from the Collaborative International Research in Clinical and Longitudinal Experience Study (CIRCLES) NMOSD biorepository. ${ }^{19}$ We applied highthroughput technologies to assess these biospecimens using a simultaneous, hypothesis-generating strategy focused on a large set of immune cell populations, cytokines, and chemokines. Statistical methods were then used to compare cell subset frequencies and serum analyte concentrations in NMOSD vs healthy controls (HC). In addition, clinical metadata were integrated into statistical modeling to assess potential relationships between molecular and cellular profiles and NMOSD relapses.

\section{Methods}

\section{Study participants and biospecimens}

PBMC and serum specimens from participants with NMOSD and HCs were collected and archived through the Guthy-
Jackson Charitable Foundation CIRCLES study ${ }^{19}$ or through a biorepository established at the Yale University School of Medicine, Department of Neurology. Written informed consent was obtained from all study participants before sample collection.

Two sets of serum samples were separately obtained and analyzed independently to avoid batch effect. These 2 serum sets were termed cohort 1 and cohort 2 .

\section{Flow cytometry immunophenotyping of cell subsets}

Five flow cytometry panels, previously validated by the Human Immune Phenotyping Consortium, ${ }^{20}$ were used to examine the frequencies of 39 immune cell subsets (table e-1, links.lww. com/NXI/A292) in unstimulated PBMCs. These panels were developed to standardize routine immunophenotyping in humans across various sites. All samples analyzed were verified to have a PBMC viability greater than $80 \%$, assessed by 7-aminoactinomycin D staining (Thermo Fisher, Waltham, MA). Briefly, samples were thawed and incubated in the dark with viability dye for 20 minutes. Following washing, PBMCs were split into $5 \times 10^{5}$ cells for each of the 5 panels. Cells were incubated with an antibody cocktail respective of each panel (table e-1, links.lww.com/NXI/A292) at $4^{\circ} \mathrm{C}$ and then analyzed on a BD Biosciences LSR Fortessa cytometer.

\section{Evaluation of serum cytokines and chemokines}

The concentrations of 46 soluble circulating cytokines/chemokines were measured using customized multiplex proteomics assays (R\&D Systems Human Magnetic Luminex Assay kit; vendor catalog no. CUST0I704/QT84038/2, LXSAHM) for each cohort. The assays were conducted according to the manufacturer's instructions. Briefly, diluted serum samples or standards were added to individual Luminex wells and incubated with the microparticle cocktail for 2 hours with agitation. Sample wells were washed and incubated in the dark with diluted biotinantibody cocktail for 1 hour at room temperature with agitation. After washing, streptavidin-PE was added to each well and incubated in the dark for 30 minutes with agitation. Last, magnetic microparticles were resuspended and read using a Luminex analyzer. The concentration of each serum analyte was then quantified using its respective standard curve.

In cohort 1, B-cell activating factor (BAFF), which was not available in that Luminex kit, was analyzed using a commercial ELISA kit (R\&D Systems, Minneapolis, MN) following manufacturer instructions. 


\section{Statistical analysis}

Flow cytometry frequencies were calculated using FlowJo v10.4. The percent frequency of each cell subset was determined by calculating the fraction of the subset population relative to its parent population. Univariate statistical analyses on immunophenotyping and serum analyte data were performed using the Welch $t$ test, and 95\% CIs of the differences of the means (with mean difference defined as meanNMOSD-meanHC) were calculated in R. To correct for multiple hypotheses testing, $q$ value or $p$-adjusted ( $p$-adj) was calculated while maintaining a $5 \%$ false discovery rate using the Storey algorithm in $\mathrm{R}$. For univariate analyses of serum analytes, $p$-adj $\leq 0.05$ was interpreted as significant, whereas for immunophenotyping, $p \leq 0.05$ was interpreted as significant. Further evaluation of univariate analyses based on rituximab treatment was performed using the Welch $t$ test, and $p \leq 0.05$ was interpreted as significant.

\section{Multivariate statistics}

To permit comparisons across serum analyte cohorts, normalization was performed by z-score normalizing assay values (subtracting the mean and dividing by the SD).

Multivariable logistic or linear regression was performed using the glm function in base R v3.4.2 for the prediction of NMOSD vs $\mathrm{HC}$ or for detecting associations with NMOSD clinical data such as days since relapse or annual relapse rate (ARR). All available serum analyte or immunophenotyping frequencies were used as variables in these models, and no data were missing during model training. $R^{2}$ (1 subtracted by the ratio of null deviance to residual deviance) was used to evaluate for goodness of fit of multivariable linear regression models. Fivefold cross validation was performed to assess models for overfitting of multivariable logistic regression models. A receiver operating characteristic (ROC) curve was computed, and the area under the curve (AUC) was calculated to assess performance using the pROC v1.15.3 $\mathrm{R}$ package. The $\mathrm{R}$ package boot v1.3-22 was used to compute CIs for AUC. Principal component analysis was performed using base $\mathrm{R}$. Mean and 95\% CIs of the mean (95\% CImean) were calculated for days since relapse and ARR. All codes used in this study are available on request. A $p$ value $\leq 0.05$ was interpreted as statistically significant.

\section{Data availability}

Anonymized data will be shared on request from qualified investigators.

\section{Results}

\section{Clinical and demographic characteristics of participants with NMOSD and HCs}

PBMC samples were provided by 12 participants with NMOSD and HCs. Serum samples were provided by 27 participants with NMOSD and 11 HCs for cohort 1 and 29 participants with NMOSD and $11 \mathrm{HCs}$ for cohort 2. Demographic and clinical characteristics of study participants are summarized in table 1. The mean age of each NMOSD and HC group for the 3 analyses ranged from 31.5 to 54.5 years. The mean disease duration ranged from 5.40 to 6.42 years. The majority of participants were female (between $67 \%$ and $84 \%$ per group). NMO-IgG serostatus was distributed between seronegative, seropositive, and unknown for all NMOSD groups.

Primary reported race or ethnicity was heterogeneous between groups, as was treatment history. At least $50 \%$ of the participants with NMOSD in each group had been treated with rituximab. Varying frequencies of participants had been treated with corticosteroid, IVIg, plasma exchange, or other immunotherapies. Participants were also heterogeneous in terms of primary symptoms and phenotypic presentation including optic neuritis or longitudinally extensive transverse myelitis.

\section{$\mathrm{CD} 16^{+} \mathrm{CD} 56^{+} \mathrm{NK}$ cell frequency is reduced in NMOSD vs HCs}

We next sought to determine whether differences in immune cell frequencies between participants with NMOSD and HCs could be identified. To that end, 5 validated flow cytometry panels that applied defined markers were used to delineate subsets of $\mathrm{T}$ lymphocytes, B lymphocytes, monocytes, natural killer (NK) cells, and dendritic cells in unstimulated PBMCs. Panel 1 measured central, effector, and naive memory $\mathrm{T}$ cells; panel 2 measured $\mathrm{CD} 4^{+} \mathrm{Th} 1$, Th2, and Th17 cells, as well as their $\mathrm{CD} 8^{+}$counterparts defined by the same markers, namely Th1-like, Th2-like, and Th17-like $\mathrm{CD} 8^{+}$cells; panel 3 measured regulatory T-cell subsets; panel 4 measured B-cell subsets; and panel 5 measured monocyte, NK cell, and dendritic cell subsets (table e-1, links.lww.com/NXI/A292). A total of 39 cell subset frequencies were analyzed in the 5 panels (table 2).

The frequency of 3 populations was significantly different between participants with NMOSD and HCs. CD $16^{+} \mathrm{CD} 56^{+}$ NK cell frequency was decreased by $54 \%$ in NMOSD vs HC (95\% CI -56.8 to $-10.4, p=0.0067)$. A reduction in $\mathrm{CD} 16^{+} \mathrm{CD} 56^{+} \mathrm{NK}$ cell frequency was still seen in the participants with NMOSD who had not been treated by rituximab (95\% CI -69.7 to $-6.45, p=0.024$ ), though not in those who had been treated by rituximab (95\% CI -62.9 to $4.72, p=$ 0.083). The frequency of Th1-like $\mathrm{CD}^{+} \mathrm{T}$ cells was also reduced in NMOSD vs HC by $53 \%$ (95\% CI -3.98 to -0.192 , $p=0.034)$. Stratification analyses based on rituximab treatment revealed that both rituximab-treated $(95 \% \mathrm{CI}-4.06$ to $-0.176, p=0.035)$ and untreated $(95 \% \mathrm{CI}-4.15$ to $-0.451, p=$ 0.019) participants with NMOSD had reduced Th1-like CD $8^{+}$ $\mathrm{T}$ cells compared with HCs. Last, the frequency of B cells overall was also lower in NMOSD than HC by $54 \%$ (95\% CI -6.33 to $-0.702, p=0.017)$. However, further analysis revealed that rituximab-untreated participants had a similar frequency of $\mathrm{B}$ cells as $\mathrm{HCs}(95 \% \mathrm{CI}-4.72$ to $3.28, p=0.685)$, and it was the rituximab-treated group who had the reduced B-cell frequency $\left(95 \% \mathrm{CI}-7.96\right.$ to $\left.-4.66, p=3.5 \times 10^{-6}\right)$. All other cell subset frequencies were similar in NMOSD compared with $\mathrm{HC}$. 
Table 1 Clinical and demographic characteristics of NMOSD and HC participants

\begin{tabular}{|c|c|c|c|c|c|c|}
\hline & \multicolumn{2}{|c|}{ Immunophenotyping } & \multicolumn{2}{|c|}{ Cohort 1: serum } & \multicolumn{2}{|c|}{ Cohort 2: serum } \\
\hline & $H C(n=12)$ & $\operatorname{NMOSD}(n=12)$ & $H C(n=11)$ & NMOSD $(n=27)$ & $H C(n=11)$ & NMOSD $(n=29)$ \\
\hline Age, $y$, mean \pm SD & $48.6 \pm 16.7$ & $44.3 \pm 13.7 / 11$ & $31.5 \pm 13.1$ & $39.5 \pm 12.9 / 24$ & $54.5 \pm 17.5$ & $31.6 \pm 16.8$ \\
\hline $\begin{array}{l}\text { Disease duration, } y \text {, } \\
\text { mean } \pm \text { SD }\end{array}$ & - & $5.55 \pm 4.36 / 11$ & - & $6.42 \pm 6.78 / 22$ & - & $5.40 \pm 5.74 / 26$ \\
\hline \multicolumn{7}{|l|}{ Sex, n (\%) } \\
\hline Female & $8(67)$ & $10(83)$ & $8(73)$ & $21 / 25(84)$ & $8(73)$ & $21(72)$ \\
\hline Male & $4(33)$ & $2(17)$ & $3(27)$ & $4 / 25(16)$ & $3(27)$ & $8(28)$ \\
\hline \multicolumn{7}{|l|}{ Serostatus, ${ }^{a}$ n (\%) } \\
\hline AQP4-IgG $^{+}$ & - & $5(42)$ & - & $9(33)$ & - & $17(59)$ \\
\hline AQP4-IgG $^{-}$ & - & $3(25)$ & - & $7(26)$ & - & $7(24)$ \\
\hline AQP4-IgG unknown & - & $4(33)$ & - & $11(41)$ & - & $5(17)$ \\
\hline \multicolumn{7}{|l|}{ Race/ethnicity, n (\%) } \\
\hline Caucasian & $9(75)$ & $10(83)$ & $8(73)$ & $7 / 21(33)$ & $8(72)$ & $20(69)$ \\
\hline Black/African American & $0(0)$ & $1(8.3)$ & $0(0)$ & $9 / 21(43)$ & $0(0)$ & $3(10)$ \\
\hline Latino/Hispanic & $0(0)$ & $1(8.3)$ & $1(9)$ & $3 / 21(14)$ & $1(9.0)$ & $5(17)$ \\
\hline Asian & $3(25)$ & $0(0)$ & $2(18)$ & 3/21 (14) & $2(18)$ & $0(0)$ \\
\hline Other $^{b}$ & $0(0)$ & $0(0)$ & $1(9)$ & $0 / 21(0)$ & $0(0)$ & $1(3.4)$ \\
\hline \multicolumn{7}{|l|}{ Treatment, n (\%) } \\
\hline Rituximab & - & $6(50)$ & - & $20(74)$ & - & $16(55)$ \\
\hline Corticosteroids & - & $8(67)$ & - & $13 / 23(57)$ & - & $8(28)$ \\
\hline Other immunotherapies & - & $6(50)$ & - & $1 / 11(9.1)$ & - & $8(28)$ \\
\hline IVIg & - & $2(17)$ & - & $0 / 11(0)$ & - & $1(3.4)$ \\
\hline PLEX & - & $1(8.3)$ & - & 1/11 (9.1) & - & $1(3.4)$ \\
\hline
\end{tabular}

Abbreviations: AQP4-IgG = aquaporin-4 immunoglobulin G; HC = healthy control; IVIg = IV immunoglobulin; NMOSD = neuromyelitis optica spectrum disorder; PLEX = plasma exchange.

If demographics or clinical data are unknown for some samples in a group, they are depicted as a fraction with the number of known samples indicated in the denominator. For example, 1/11 (9.1) for PLEX under treatment means that of the 11 samples for which PLEX treatment status is known, 1, or 9.1\%, had undergone PLEX treatment.

${ }^{a}$ Serostatus was determined using standard methods approved for NMOSD diagnosis and confirmed by the site investigator.

b The "Other" category includes American Indian, First Canadian, Alaskan Native, Hawaiian Native, Pacific Islander, or another specified racial/ethnic identity.

\section{Analysis of serum analytes validates NMOSD biomarkers}

Serum analyte concentrations were measured using multiplex proteomics assays and ELISA in 2 independent cohorts. A total of 46 serum cytokines or chemokines were measured in each cohort; 4 of these differed significantly between NMOSD and HC in one or both cohorts (table 3). BAFF was elevated in NMOSD samples in cohorts $1\left(95 \% \mathrm{CI} 671-1,430, p\right.$-adj $\left.=1.6 \times 10^{-4}\right)$ and $2(95 \%$ CI 1,360-3,880, $p$-adj $=0.0028$ ). As rituximab treatment has been shown to elevate serum BAFF, ${ }^{18}$ we evaluated whether BAFF serum concentration differed based on previous rituximab treatment. The groups, arranged in ascending order of BAFF concentration, are HC, untreated NMOSD, all (unstratified) NMOSD, and treated NMOSD. In both cohorts, BAFF concentration was elevated in rituximab-treated NMOSD (cohort 1 :
95\% CI 769-1,650, $p=1.3 \times 10^{-5}$; cohort 2: 95\% CI 2,740-6,190, $p=4.7 \times 10^{-4}$ ) in comparison to HC. In cohort 2 , the serum BAFF concentration was elevated in rituximab-treated NMOSD compared with untreated (95\% CI 1740-5,620, $p=0.00065)$. In summary, the rituximab-treated and unstratified NMOSD groups had significantly elevated serum BAFF in both cohorts. The use of 2 independent cohorts and 2 different methods (ELISA and multiplex proteomics assay) validated BAFF as a significant result.

The 3 other serum analytes that differed between NMOSD and HC were interleukin (IL)-6 (95\% CI 0.500-1.97, $p$-adj $=0.013)$, CCL22 (95\% CI 104-504, $p$-adj = 0.019), and CCL3 (95\% CI 8.49-50.7, $p$-adj $=0.027)$, which were all elevated in cohort 2 only. IL-17F, S100B, FGF-basic, IL-15, RANTES, and IL-1RA did not meet the threshold for significance ( $p$-adj $\leq 0.05$ ), but 
Table 2 Mean immune cell frequencies in NMOSD and HC PBMC samples

\begin{tabular}{|c|c|c|c|c|c|}
\hline Cell subset & $\mathrm{HC}$ & NMOSD & Difference $(95 \% \mathrm{Cl})$ & $p$ Value & $p$-adj \\
\hline $\mathrm{CD}_{16}{ }^{+} \mathrm{CD} 56^{+} \mathrm{NK} / \mathrm{NK}$ cells & 65.4 & 31.9 & -56.8 to -10.4 & 0.0067 & 0.31 \\
\hline B cells/viable CD3 $^{-}$ & 6.46 & 2.94 & -6.33 to -0.702 & 0.017 & 0.31 \\
\hline Th1-like/CD8 ${ }^{+} T$ cells $^{a}$ & 3.95 & 1.87 & -3.98 to -0.192 & 0.034 & 0.45 \\
\hline Central memory/CD8 ${ }^{+} \mathrm{T}$ cells & 5.08 & 9.57 & -1.03 to 9.99 & 0.10 & 0.70 \\
\hline $\begin{array}{l}\text { CD16 }^{-} \text {CD56 bright } \\
\text { NK/NK cells }\end{array}$ & 3.71 & 5.85 & -0.479 to 4.75 & 0.10 & 0.70 \\
\hline Naive/B cells & 61.7 & 45.8 & -37.3 to 5.68 & 0.13 & 0.70 \\
\hline Memory CCR4 ${ }^{+} /$Tregs & 0.88 & 0.295 & -1.39 to 0.225 & 0.14 & 0.70 \\
\hline $\mathrm{CXCR5}^{+} \mathrm{PD}^{-}{ }^{-} / \mathrm{CD}^{+}{ }^{+} \mathrm{T}$ cells & 5.40 & 3.82 & -3.77 to 0.603 & 0.15 & 0.70 \\
\hline Activated $/ \mathrm{CD8}^{+} \mathrm{T}$ cells & 1.22 & 2.75 & -0.771 to 3.82 & 0.17 & 0.70 \\
\hline $\begin{array}{l}\text { T follicular } \\
\text { helper/CD4 } 4^{+} \mathrm{T} \text { cells }\end{array}$ & 1.31 & 0.541 & -1.96 to 0.414 & 0.18 & 0.70 \\
\hline Activated CCR4 ${ }^{+} /$Tregs & 0.129 & 0.383 & -0.133 to 0.641 & 0.18 & 0.70 \\
\hline $\mathrm{CD8}^{+}$T/viable $\mathrm{CD}^{+}$ & 26.2 & 22.4 & -10.4 to 2.72 & 0.24 & 0.74 \\
\hline Treg/CD4 ${ }^{+} \mathrm{T}$ cells & 1.96 & 2.66 & -0.582 to 1.99 & 0.26 & 0.74 \\
\hline NK cells/viable $\mathrm{CD}^{-} 19^{-} 20^{-}$ & 31.5 & 25.6 & -16.7 to 4.83 & 0.26 & 0.74 \\
\hline Effector/CD4 ${ }^{+} \mathrm{T}$ cells & 5.97 & 10.8 & -5.63 to 15.2 & 0.35 & 0.83 \\
\hline Effector memory/CD8 ${ }^{+} \mathrm{T}$ cells & 42.4 & 36.2 & -19.8 to 7.25 & 0.35 & 0.83 \\
\hline Th2-like/CD8 ${ }^{+} T$ cells ${ }^{a}$ & 0.563 & 0.340 & -0.711 to 0.265 & 0.35 & 0.83 \\
\hline DCs/Lin ${ }^{-}$NK-subset & 12.9 & 17.3 & -6.53 to 15.4 & 0.40 & 0.86 \\
\hline $\begin{array}{l}\text { Plasmablasts/CD19+CD20- } \\
\text { viable } \mathrm{CD3}^{-}\end{array}$ & 6.90 & 4.14 & -9.78 to 4.24 & 0.42 & 0.86 \\
\hline IgD $^{-}$memory/B cells & 9.51 & 12.8 & -5.84 to 12.3 & 0.45 & 0.86 \\
\hline IgD ${ }^{+}$memory/B cells & 10.6 & 16.3 & -10.5 to 21.9 & 0.46 & 0.86 \\
\hline Plasmacytoid DCs/DCs & 25.9 & 22.6 & -13.8 to 7.27 & 0.52 & 0.86 \\
\hline $\mathrm{CD}^{+}{ }^{+}$cells/viable $\mathrm{CD}^{+}$ & 56.7 & 53.3 & -15.2 to 8.51 & 0.56 & 0.86 \\
\hline Monocytes/Lin ${ }^{-}$NK-subset & 43.3 & 39.7 & -15.9 to 8.78 & 0.56 & 0.86 \\
\hline Th17-like/CD8 ${ }^{+}$cells $^{a}$ & 1.45 & 1.76 & -0.899 to 1.52 & 0.60 & 0.86 \\
\hline $\mathrm{CD}^{2} 5 \mathrm{RO}^{+} / \mathrm{CD}^{+} \mathrm{T}$ cells & 37.0 & 33.2 & -19.9 to 12.3 & 0.62 & 0.86 \\
\hline Activated/CD4 ${ }^{+} \mathrm{T}$ cells & 0.470 & 0.383 & -0.445 to 0.278 & 0.63 & 0.86 \\
\hline Naive/CD4 ${ }^{+} \mathrm{T}$ cells & 42.5 & 37.9 & -23.8 to 14.8 & 0.63 & 0.86 \\
\hline $\mathrm{Th}_{1 / \mathrm{CD}^{+}} \mathrm{T}^{\mathrm{T}}$ cells & 4.83 & 6.00 & -4.45 to 6.79 & 0.66 & 0.86 \\
\hline Naive/CD8 ${ }^{+} \mathrm{T}$ cells & 25.6 & 28.7 & -12.2 to 18.5 & 0.67 & 0.86 \\
\hline Th17/CD4 ${ }^{+} \mathrm{T}$ cells & 3.49 & 3.07 & -3.26 to 2.43 & 0.76 & 0.91 \\
\hline $\begin{array}{l}\text { Central memory/CD4 } \\
\text { T cells }\end{array}$ & 28.8 & 27.2 & -14.6 to 11.3 & 0.79 & 0.91 \\
\hline Naive CCR4 ${ }^{+} /$Tregs & 1.74 & 2.01 & -1.93 to 2.47 & 0.80 & 0.91 \\
\hline Myeloid DCs/DCs & 41.9 & 43.4 & -12.1 to 15.2 & 0.81 & 0.91 \\
\hline Effector/CD8 ${ }^{+} \mathrm{T}$ cells & 27.0 & 25.6 & -16.5 to 13.7 & 0.85 & 0.91 \\
\hline Effector memory/CD4 ${ }^{+} \mathrm{T}$ cells & 22.7 & 24.2 & -15.5 to 18.3 & 0.86 & 0.91 \\
\hline
\end{tabular}


Table 2 Mean immune cell frequencies in NMOSD and HC PBMC samples (continued)

\begin{tabular}{|c|c|c|c|c|c|}
\hline Cell subset & $\mathrm{HC}$ & NMOSD & Difference $(95 \% \mathrm{Cl})$ & $p$ Value & $p$-adj \\
\hline Th2 $/ \mathrm{CD4}^{+} \mathrm{T}$ cells & 0.661 & 0.642 & -0.499 to 0.460 & 0.93 & 0.94 \\
\hline $\mathrm{CCR4}^{+} / \mathrm{Tregs}$ & 20.2 & 21.0 & -17.4 to 19.0 & 0.93 & 0.94 \\
\hline Transitional/B cells & 7.72 & 7.92 & -5.60 to 6.00 & 0.94 & 0.94 \\
\hline
\end{tabular}

Abbreviations: $\mathrm{DC}=$ dendritic cell; $\mathrm{HC}=$ healthy control; NK cells = natural killer cells; NMOSD = neuromyelitis optica spectrum disorder; $p$-adj $=p$-adjusted $(q-$ value); $\mathrm{PBMC}=$ peripheral blood mononuclear cell; Tregs = regulatory T cells.

Statistical analysis was performed using the Welch $t$ test and Storey adjustment for multiple comparisons, and serum analytes with $p \leq 0.05$ are bolded. Cell subsets are in ascending order of $p$ value.

${ }^{a}$ Th1-like, Th2-like, and Th17-like CD8 ${ }^{+}$T cells are the CD8 ${ }^{+}$correlates of $C D 4^{+}$Th1, Th2, and Th17 subtypes, based on marker expression.

were elevated in NMOSD in 1 cohort $(p \leq 0.05)$. All other serum analyte concentrations in NMOSD were similar to HC.

\section{Multivariable logistic regression identifies BAFF association with NMOSD}

We performed multivariable logistic regression analyses to model the association of serum analyte concentrations or immunophenotyping frequencies with NMOSD. The ability to predict NMOSD was assessed using 5-fold cross validation evaluated through quantification of the AUC of the associated ROC curve (figure 1, A-D; table 4). Models constructed on immunophenotyping and serum analyte concentrations from both cohorts had a greater predictive ability $(0.7<$ AUC $<$ $0.8)$ than models constructed on serum analyte concentrations from cohort 1 or 2 alone $(0.5<$ AUC $<0.7)$. The model based on serum analytes from both cohorts had the highest AUC (0.734) and standard accuracy value (0.700) and was further analyzed to identify significant parameters.

In the multivariate serum analyte model based on both cohorts, BAFF concentration was found to be associated with NMOSD ( $p=0.022$, figure $1 \mathrm{E})$, consistent with observations from univariate analyses. BAFF concentration remained associated with NMOSD in this model when rituximab treatment was included as a covariate $(p=0.038)$. A multivariable logistic regression model constructed on cohort 1 and tested on cohort 2 performed with an AUC of 0.66 and accuracy of 0.58 , suggesting weak generalizability between cohorts (figure $1, \mathrm{~F}$ and $\mathrm{G}$ ). The cohort 1-trained model was a relatively poor predictor $(A U C<0.7)$ of NMOSD in cohort 2.

A separation of NMOSD and HC was observed when visualizing components 1 and 2 derived from principal component analysis (figure e-1, A-D, links.lww.com/NXI/A291). These components explained only $45 \%$ and $25 \%$, respectively, of the total variance from immunophenotyping and serum analytes (both cohorts). We did not observe distinct clustering based on these analyses. Principal components 1 and 2 explained 73\% and $78 \%$ of the total variance of cohorts 1 and 2, respectively. Although clustering was still not observed in these decompositions, some NMOSD samples did separate. No differentiation of samples was seen based on institutional source or cohort (figure e-1, E-J, links.lww.com/NXI/A291). In general, principal component analysis of immunophenotyping or serum analyte data sets could not reliably distinguish NMOSD vs HC.

\section{Serum CX3CL1 concentration correlates with days since relapse}

We next sought to investigate whether measured serum analyte concentrations correlated with temporal measures of clinical outcome, particularly the number of days since relapse or ARR. The mean number of days since relapse was 590 (95\% CImean 350-820), and the mean ARR was 0.8 (95\% CImean 0.5-1.2). Multivariable linear regression models were used to identify associations between cohort 1 and 2 serum analyte levels and the 2 outcome variables. These models fit weakly, though better for days since relapse $\left(R^{2}=0.602\right)$ than $\operatorname{ARR}\left(R^{2}=0.361\right)$. Statistical analysis of serum analyte parameters (table e-2, links.lww.com/ $\mathrm{NXI} / \mathrm{A} 292$ ) revealed that the chemokine CX3CL1 (fractalkine; $p$ $=0.031)$ was associated with days since relapse. This association indicated that CX3CL1 levels in serum decline as a function of time since previous relapse. No other serum analyte was significant in our multivariable linear regression analyses for either outcome.

\section{Discussion}

The goal of this exploratory study was to assess circulating immune cell and cytokine/chemokine profiles using an unbiased and hypothesis-generating strategy. This approach achieved 3 overarching goals, which were to (1) verify the utility of the CIRCLES biospecimen repository in supporting molecular and cellular NMOSD research, (2) reference known biomarkers as a means of validation using external standards, and (3) identify potentially novel candidate NMOSD biomarkers. With the high-throughput evaluation of a large set of circulating immune cell frequencies and serum cytokine and chemokine concentrations, we have validated previously identified biomarkers. Beyond this concordance, the current studies have also identified $\mathrm{CD} 16^{+} \mathrm{CD} 56^{+} \mathrm{NK}$ cells and $\mathrm{CX} 3 \mathrm{CL} 1$ as intriguing and novel biomarker candidates to be further evaluated for possible NMOSD predictive or prognostic applications.

A significant decrease in peripheral NK cell frequency has been reported in patients with NMOSD in comparison to patients with $\mathrm{MS}$ and $\mathrm{HCs} .{ }^{21}$ However, stratification by clinical status 


\begin{tabular}{|c|c|c|c|c|c|c|c|c|}
\hline \multirow[b]{2}{*}{ Analyte } & \multicolumn{4}{|l|}{ Cohort 1} & \multicolumn{4}{|l|}{ Cohort 2} \\
\hline & $\mathrm{HC}, \mathrm{pg} / \mathrm{mL}$ & NMOSD, pg/mL & Difference $(95 \% \mathrm{CI})$ & $p$ Value ( $p$-adj) & $\mathrm{HC}, \mathrm{pg} / \mathrm{mL}$ & NMOSD, pg/mL & Difference $(95 \% \mathrm{Cl})$ & $p$ Value (p-adj) \\
\hline BAFF & 527 & 1,580 & 671 to 1,430 & $4.4 \times 10^{-6}\left(1.6 \times 10^{-4}\right)$ & 1,350 & 3,970 & 1,360 to 3,880 & $1.8 \times 10^{-4}(0.0028)$ \\
\hline IL-6 & - & - & - & $\mathrm{BL}$ & 1.81 & 3.04 & 0.500 to 1.97 & $0.0018(0.013)$ \\
\hline CCL22 & 332 & 314 & -85.9 to 48.9 & $0.58(0.78)$ & 469 & 773 & 104 to 504 & $0.0038(0.019)$ \\
\hline CCL3 & 116 & 87.4 & -145 to 87.5 & $0.61(0.78)$ & 98.6 & 128 & 8.49 to 50.7 & $0.0071(0.027)$ \\
\hline S100B & - & - & - & $B L$ & 46.9 & 90.1 & 6.12 to 80.4 & $0.024(0.072)$ \\
\hline FGF-basic & - & - & - & $B L$ & 1.11 & 1.57 & 0.0262 to 0.884 & $0.038(0.089)$ \\
\hline IL-15 & - & - & - & $B L$ & 4.00 & 4.57 & 0.00840 to 1.14 & $0.047(0.089)$ \\
\hline IL-1RA & 534 & 571 & -186 to 259 & $0.74(0.88)$ & 702 & 1,130 & 6.65 to 856 & $0.047(0.089)$ \\
\hline TGF-a & - & - & & $B L$ & 5.00 & 5.89 & -0.102 to 1.88 & $0.077(0.12)$ \\
\hline CCL2 & 1,378 & 163 & -16.6 to 67.9 & $0.23(0.51)$ & 530 & 410 & -303 to 64.1 & $0.19(0.21)$ \\
\hline CX3CL1 & 553 & 566 & -143 to 168 & $0.87(0.89)$ & 932.9 & 1,147 & -136 to 564 & $0.22(0.21)$ \\
\hline IP-10 & 14.1 & 15.5 & -4.55 to 7.43 & $0.63(0.78)$ & 19.3 & 25.2 & -4.01 to 15.9 & $0.23(0.21)$ \\
\hline APRIL & - & - & & NA & 1,830 & 2,200 & -260 to 1,010 & $0.24(0.21)$ \\
\hline FLT-3L & 35.1 & 36.2 & -6.42 to 8.55 & $0.77(0.88)$ & 73.2 & 88.5 & -10.8 to 41.5 & $0.24(0.21)$ \\
\hline IL-1a & 1.71 & 1.75 & -0.0297 to 0.125 & $0.22(0.51)$ & 4.20 & 4.28 & -0.0543 to 0.210 & $0.24(0.21)$ \\
\hline IL-13 & - & - & - & $B L$ & 419 & 686 & -261 to 794 & $0.31(0.21)$ \\
\hline IL-21 & - & - & - & NA & 9.90 & 12.2 & -2.26 to 6.76 & $0.32(0.21)$ \\
\hline CCL4 & 130 & 115 & -187 to 155 & $0.85(0.89)$ & 366 & 208 & -509 to 195 & $0.35(0.21)$ \\
\hline G-CSF & - & - & & $B L$ & 14.4 & 18.3 & -4.89 to 12.8 & $0.37(0.21)$ \\
\hline CCL7 & - & - & - & $B L$ & 91.0 & 89.2 & -7.07 to 3.46 & $0.48(0.24)$ \\
\hline Eotaxin & 55.9 & 71.2 & -0.199 to 30.8 & $0.053(0.32)$ & 120 & 105 & -59.9 to 29.6 & $0.49(0.24)$ \\
\hline
\end{tabular}


Table 3 Mean NMOSD and HC serum analyte concentrations in 2 cohorts (continued)

\begin{tabular}{|c|c|c|c|c|c|c|c|c|}
\hline \multirow[b]{2}{*}{ Analyte } & \multicolumn{4}{|l|}{ Cohort 1} & \multicolumn{4}{|l|}{ Cohort 2} \\
\hline & $\mathrm{HC}, \mathrm{pg} / \mathrm{mL}$ & NMOSD, pg/mL & Difference $(95 \% \mathrm{Cl})$ & $p$ Value ( $p$-adj) & $\mathrm{HC}, \mathrm{pg} / \mathrm{mL}$ & NMOSD, pg/mL & Difference $(95 \% \mathrm{Cl})$ & $p$ Value ( $p$-adj) \\
\hline L-31 & - & - & - & $B \mathrm{~L}$ & 138 & 165 & -51.2 to 106 & $0.49(0.24)$ \\
\hline L-16 & - & - & - & NA & 159 & 175 & -43.7 to 76.0 & $0.59(0.26)$ \\
\hline L-7 & 2.83 & 3.03 & -0.280 to 0.672 & $0.41(0.67)$ & 8.61 & 9.64 & -2.82 to 4.88 & $0.59(0.26)$ \\
\hline L-27 & - & - & - & $B \mathrm{~L}$ & 164 & 158 & -39.8 to 27.7 & $0.72(0.30)$ \\
\hline Eotaxin-2 & 535 & 463 & -276 to 131 & $0.47(0.73)$ & 1,760 & 1,570 & $-1,480$ to 1,100 & $0.76(0.31)$ \\
\hline L-4 & 2.63 & 3.2 & -0.525 to 1.72 & $0.29(0.58)$ & 23.60 & 23.73 & -0.835 to 1.08 & $0.80(0.32)$ \\
\hline CD40L & 2,370 & 2,470 & -638 to 834 & $0.79(0.88)$ & 5,120 & 5,200 & $-2,040$ to 2,220 & $0.93(0.36)$ \\
\hline L-33 & - & - & - & $B \mathrm{~L}$ & 16.5 & 16.6 & -3.84 to 4.08 & $0.95(0.36)$ \\
\hline L-17F & 335 & 507 & 38.4 to 306 & $0.013(0.24)$ & - & - & - & NA \\
\hline RANTES & 679 & 1,120 & 8.68 to 875 & $0.046(0.32)$ & - & - & - & NA \\
\hline L-3 & 5.65 & 6.72 & -0.189 to 2.32 & $0.093(0.42)$ & - & - & - & $B \mathrm{~L}$ \\
\hline DGGF-BB & 11.3 & 46.2 & -42.1 to 112 & $0.36(0.62)$ & - & - & - & NA \\
\hline DGF-AA & 94.6 & 109 & -40.6 to 69.5 & $0.60(0.78)$ & - & - & - & NA \\
\hline
\end{tabular}

Abbreviations: $\mathrm{BL}=$ concentration below limit for analysis; $\mathrm{HC}=$ healthy control; NA = not available; NMOSD = neuromyelitis optica spectrum disorder; $p$-adj $=p$-adjusted ( $q$-value).

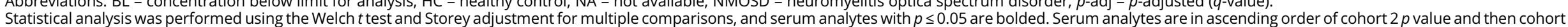

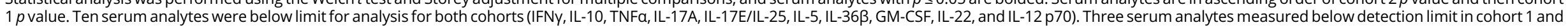
were not analyzed in cohort 2 (LT-a, IL-12 p40, and IL-11), and 3 serum analytes measured below detection limit in cohort 2 and were not analyzed in cohort 1 (IL-9, TNF 3 , and IL-23). 

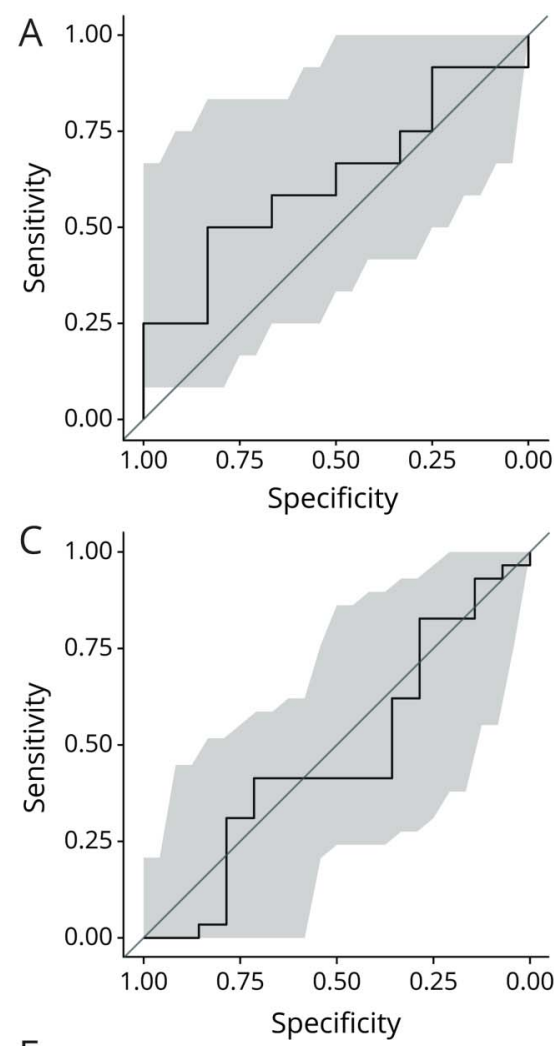

$\mathrm{E}$

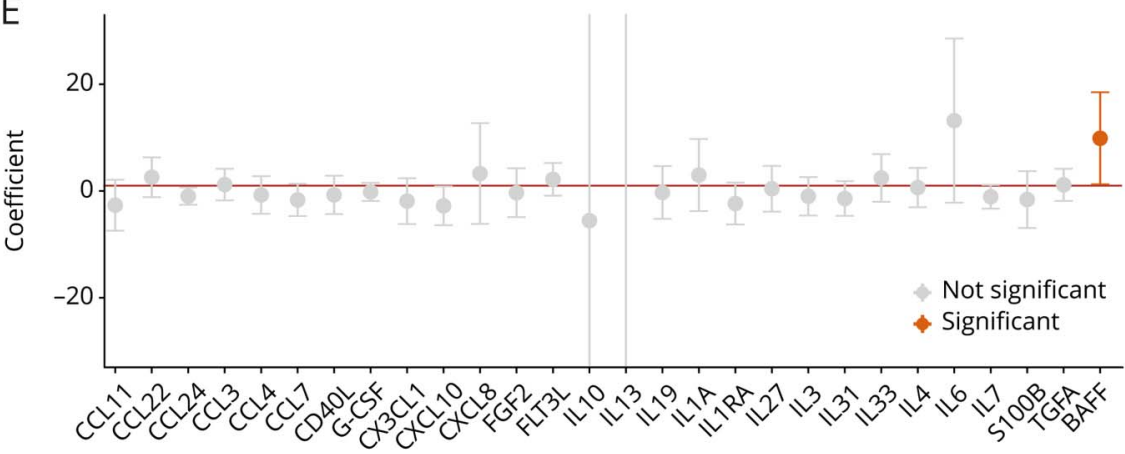

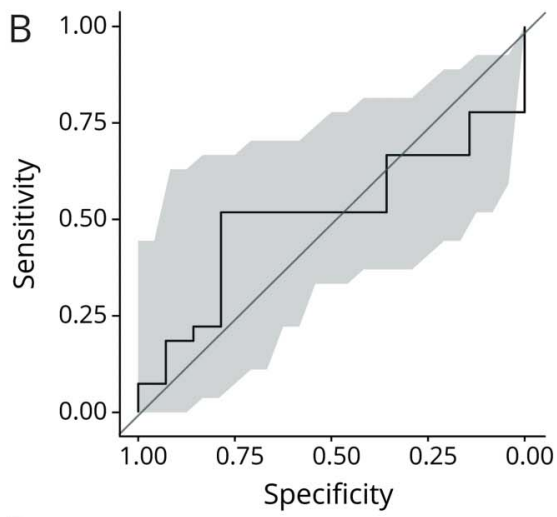

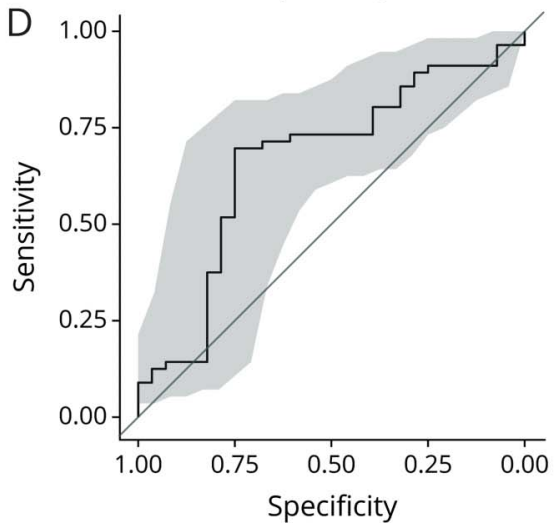

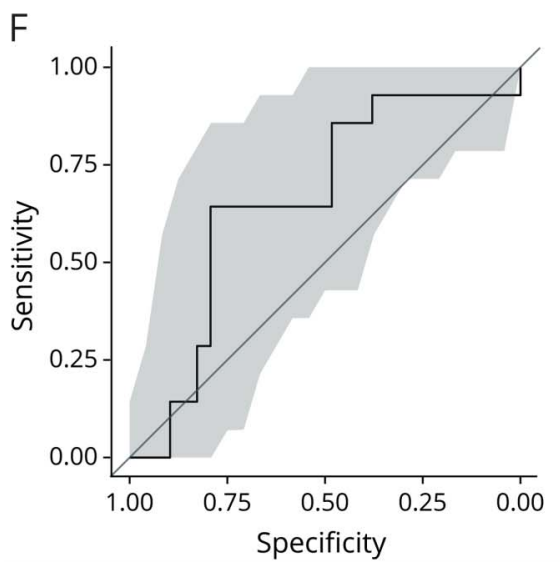

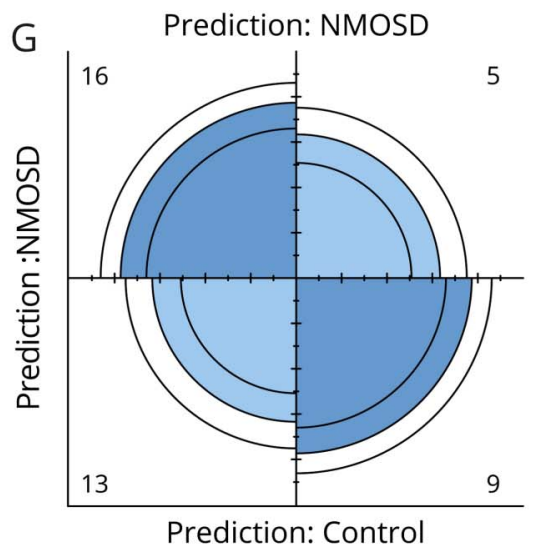

ROC curves for 5 -fold cross validation of multivariable logistic regression models were constructed for NMOSD predictability based on (A) immunophenotyping, (B) cohort 1, (C) cohort 2, and (D) cohorts 1 and 2 serum analyte concentrations. Combined serum cohort and immunophenotyping models have better predictive value than models constructed on cohorts 1 or 2 alone. (E) Coefficients for the combined cohort model are depicted with SD. BAFF concentration was significantly associated with NMOSD $(p=0.022$, in orange). Cohort 2 was tested on a multivariable regression model for cohort 1 , for which the (F) ROC curve and (G) confusion matrix are shown. They revealed an AUC of 0.66 and accuracy of 0.58 . AUC = area under the curve; NMOSD $=$ neuromyelitis optica spectrum disorder; $R O C=$ receiver operating characteristic; $p \leq 0.05$ was considered statistically significant.

revealed that only patients with relapsing NMOSD had significantly less NK cells; those in remission did not. ${ }^{21}$ Therefore, NK cell frequency may be a candidate biomarker with temporal specificity. In this study, we did not find a significant change in total NK cell frequency, although we found a decrease in $\mathrm{CD} 16^{+} \mathrm{CD} 56^{+} \mathrm{NK}$ cell subset frequency in participants with 
Table 4 AUC and ACC for multivariable logistic regression curves

\begin{tabular}{lll}
\hline Data & AUC, mean \pm SD & ACC, mean \pm SD \\
\hline Immunophenotyping & $0.700 \pm 0.217$ & $0.530 \pm 0.157$ \\
\hline Serum analytes: cohort 1 & $0.634 \pm 0.239$ & $0.464 \pm 0.163$ \\
\hline Serum analytes: cohort 2 & $0.503 \pm 0.206$ & $0.444 \pm 0.193$ \\
\hline Serum analytes: both & $0.734 \pm 0.143$ & $0.700 \pm 0.142$ \\
\hline
\end{tabular}

Abbreviations: $\mathrm{ACC}=$ standard accuracy value; $\mathrm{AUC}=$ area under the curve; $\mathrm{ROC}=$ receiver operating characteristic.

NMOSD. Of note, CD16 ${ }^{+} \mathrm{NK}$ cells express perforin and are cytotoxic; they are involved in antibody-dependent cellular cytotoxicity, which is a mechanism associated with NMOSD pathogenesis. $^{22,23}$ Although histopathologic examination of NMOSD lesions has not identified NK cells as a predominant infiltrating cell type, studies conducted in vitro or with mouse models have demonstrated NMO-IgG-dependent astrocyte killing by NK cells, highlighting a possible mechanism for NMOSD pathology. ${ }^{24-26}$ Other studies elucidate a protective role of NK cells in an autoimmune demyelinating disease model and a reduction in NK cell frequency in patients with MS. ${ }^{27,28}$ Our findings provide impetus for further inquiry into $\mathrm{CD} 16^{+} \mathrm{CD} 56^{+} \mathrm{NK}$ cells and their functions in association with NMOSD relapses in a larger patient sample.

CX3CL1 is also a viable novel biomarker candidate for further study in NMOSD. We found that CX3CL1 was significantly associated with the number of days since relapse in a multivariable linear regression model. CX3CL1, also known as fractalkine, was originally called neurotactin due to its high expression in the CNS, including by astrocytes. ${ }^{29,30}$ CX3CL1 is important for chemotaxis of leukocytes to the CNS and is commonly studied in the context of neurologic disease. For example, CX3CL1 is elevated in the serum of patients with MS. $^{31}$ Its receptor, CX3CR1, is expressed on microglia, monocytes, dendritic cells, and especially NK cells. ${ }^{32}$ Notably, $\mathrm{CD} 16^{+} \mathrm{NK}$ cells highly express CX3CR $1,{ }^{33}$ and variations in CX3CR1 are correlated with age-related macular degeneration. ${ }^{34}$ These collective findings reinforce our current data suggesting that CX3CL1 is an intriguing candidate for further study in the context of NMOSD relapse prediction.

BAFF elevation as a result of rituximab treatment is a recognized phenomenon and has been implicated in relapses occurring immediately subsequent to rituximab dosing. ${ }^{18}$ Ostensibly, the depletion of B cells causes a compensatory elevation in BAFF, promoting B-cell activation and disease recrudescence. Elevated BAFF levels have been observed in the CSF and serum of patients with NMOSD. ${ }^{35,36}$ Autoreactive B cells are especially dependent on BAFF for survival; BAFF selectively rescues autoreactive $\mathrm{B}$ cells from elimination. ${ }^{37}$ Elevated BAFF concentration has been observed in other autoimmune diseases as well, including systemic lupus erythematosus, Sjogren syndrome, and rheumatoid arthritis, and it correlates with disease status. ${ }^{38,39}$ In the present study, BAFF was significantly elevated in both study cohorts in unstratified NMOSD groups. Furthermore, BAFF was significantly associated with NMOSD in a multivariable logistic regression model, even with rituximab treatment used as a covariate. Therefore, our analyses are consistent with previous studies identified BAFF as an NMOSD biomarker.

The current findings were supported by the observation that treatment history is associated with immunophenotyping frequencies and serum analyte concentrations. For example, we observed a significant reduction in B-cell frequency in NMOSD samples in relation to rituximab treatment. This outcome was anticipated, given that rituximab depletes $\mathrm{CD} 20^{+} \mathrm{B}$ cells from peripheral circulation. However, rituximab also depletes non-B-cell $\mathrm{CD} 20^{+}$cells, such as a small population of $\mathrm{CD}^{+}{ }^{+}$T lymphocytes. ${ }^{40}$ Of interest, $\mathrm{CD} 20^{+}$ T cells are more likely to be $\mathrm{CD} 8^{+},{ }^{40}$ and we observed that the frequency of Th1-like $\mathrm{CD} 8^{+} \mathrm{T}$ cells was significantly reduced in participants with NMOSD with a history of rituximab therapy. Thus, this study may provide support for the hypothesis that rituximab treatment affects cell subsets beyond $\mathrm{CD}^{+} 0^{+} \mathrm{B}$ cells and therefore may contribute to its mechanism(s) of action. This concept deserves additional investigation. Steroids and other preventive treatments used for their immunosuppressive properties are also likely to affect immune cell frequencies and serum analyte concentrations. Here, sample sizes for other treatments were not sufficient for analysis by stratification, given that stratification by treatment requires sizable cohorts. Compounded by the rarity of NMOSD, treatment heterogeneity and limited treatmentnaive patients are challenges to biomarker discovery in NMOSD. However, treated patients should be evaluated for prognostic biomarkers, given such biomarkers would have greater value if they predicted a potential relapse regardless of treatment.

Taken together, the present findings provide impetus for further study of CX3CL1 and $\mathrm{CD} 16^{+} \mathrm{CD} 56^{+} \mathrm{NK}$ cells as potential novel biomarker candidates specifically associated with NMOSD and its relapse patterns. Considering that the elevation of serum CCL22, IL-6, and CCL3 was not validated by a second cohort, it remains to be determined whether significantly different concentrations would be found in larger NMOSD cohorts. Therefore, these serum analytes should be further validated for consideration as biomarkers, as should Th1-like $\mathrm{CD}^{+} \mathrm{T}$ cells. Future studies involving larger cohorts may reveal that these or other immunologic constituents, either alone or as components of composite signatures, represent important indicators of disease status. In any case, the current studies affirm the use of high-throughput techniques for biomarker identification in larger NMOSD cohorts. It would be informative to reevaluate the predictive value of multivariable models and principal component analyses using a larger cohort and further stratification based on treatment, relapse recency, and other clinical factors. Larger sample sizes, assessment of 
biospecimens from clinical trials, and investigation of samples drawn immediately before and after relapse events might display improved delineation of NMOSD from HC in multivariable models. We were not able to assess the correlation between immunophenotyping and clinical outcomes due to limited relapse data in these study participants (only 4 participants had paired relapse data).

Our findings provide validation for the use of high-throughput technologies, particularly multipanel flow cytometry and multiplex proteomics assay, for identification of candidate NMOSD biomarkers. Furthermore, we have identified CX3CL1 and $\mathrm{CD} 16^{+} \mathrm{CD} 56^{+} \mathrm{NK}$ cells as intriguing and novel prognostic biomarker candidates for further study. Based on these findings, for future evaluation of large NMOSD cohorts with high-throughput techniques, we propose (1) appropriate and standardized collection and storage of samples, as in the CIRCLES program or clinical trials; (2) verification of sample quality, such as PBMC viability quantification; (3) collection of paired information on treatment and clinical characteristics, such as relapse data; and (4) controlling for or stratification analyses based on treatment history, current treatment regimen, and/or clinical characteristics.

\section{Acknowledgment}

The authors thank Dr. Lesley Devine, Scientific Director of the Immune Monitoring Core Facility at Yale School of Medicine, for assisting with the FACS and proteomics assay. The authors also appreciate the efforts of the following individuals: Yanet Babcock, J. Michael Dean, Colleen Farrell, Haojun Feng, Susan Filomena, Toni Ganaway, Myka BarnesGarcia, Samuel Glaisher, Rivka Green, Elizabeth Gonzales, Elaine Hsu, Catherine J. Johnson, Ilana Katz Sand, Ilya Kister, Marlene Keymolen Ramirez, Allyson Reid, Pavle Repovic, Gloria Rodriguez, Jennifer L. Sedlak, Nancy L. Sicotte, Angela Stangorone, Ben W. Thrower, Anthony L. Traboulsee, and Gabriella Tosto. The CIRCLES project team including site PIs and coordinators, the DCC team, and the GJCF and its advisors are grateful to study participants, caregivers, and families who participated in this study. The CIRCLES project is supported by the Guthy-Jackson Charitable Foundation.

\section{Study funding}

Supported by the Guthy-Jackson Charitable Foundation and its CIRCLES research and biorepository program.

\section{Disclosure}

S. S. Yandamuri, R. Jiang, A. Sharma, E. Cotzomi, C. Zografou, A. K. Ma, J. S. Alvey, and L. J. Cook report no disclosures. T. J. Smith is a paid consultant for Horizon Therapeutics and Immunovant; has been issued US patents for the diagnosis and treatment of autoimmune diseases with IGF-I receptor monoclonal antibodies; and is a medical advisor to the Guthy-Jackson Charitable Foundation. Michael R. Yeaman is founder of NovaDigm Therapeutics Inc. developing novel vaccines and immunotherapeutics and Metacin, Inc. developing novel neuroscience pattern recognition tools; has received honoraria from Alexion Inc. and Genentech-Roche
Inc.; is a member of the Genentech-Roche Inc. Scientific Advisory Committee; and is Chair medical advisor to the Guthy-Jackson Charitable Foundation. K. C. O’Connor has received research support from Ra Pharma; is a consultant and equity shareholder of Cabaletta Bio; and is the recipient of a sponsored research subaward from the University of Pennsylvania, the primary financial sponsor of which is Cabaletta Bio. Go to Neurology.org/NN for full disclosures.

\section{Publication history}

Received by Neurology: Neuroimmunology \& Neuroinflammation April 12, 2020. Accepted in final form June 19, 2020.

Appendix 1 Authors

\begin{tabular}{|c|c|c|}
\hline Name & Location & Contribution \\
\hline $\begin{array}{l}\text { Soumya S. } \\
\text { Yandamuri, } \\
\text { MSE, PhD }\end{array}$ & $\begin{array}{l}\text { Yale University, } \\
\text { New Haven }\end{array}$ & $\begin{array}{l}\text { Analyzed data, interpreted data, } \\
\text { acquired data, and drafted } \\
\text { manuscript for intellectual content }\end{array}$ \\
\hline Ruoyi Jiang, MS & $\begin{array}{l}\text { Yale University, } \\
\text { New Haven }\end{array}$ & $\begin{array}{l}\text { Performed multivariate statistical } \\
\text { analyses and modeling and } \\
\text { contributed to manuscript writing }\end{array}$ \\
\hline $\begin{array}{l}\text { Aditi Sharma, } \\
\text { MBBS }\end{array}$ & $\begin{array}{l}\text { Yale University, } \\
\text { New Haven }\end{array}$ & $\begin{array}{l}\text { Acquired data, analyzed data, and } \\
\text { contributed to manuscript writing }\end{array}$ \\
\hline $\begin{array}{l}\text { Elizabeth } \\
\text { Cotzomi, BS }\end{array}$ & $\begin{array}{l}\text { Yale University, } \\
\text { New Haven }\end{array}$ & Acquired data and analyzed data \\
\hline $\begin{array}{l}\text { Chrysoula } \\
\text { Zografou, PhD }\end{array}$ & $\begin{array}{l}\text { Yale University, } \\
\text { New Haven }\end{array}$ & $\begin{array}{l}\text { Analyzed data and revised the } \\
\text { manuscript }\end{array}$ \\
\hline $\begin{array}{l}\text { Anthony K. Ma, } \\
\text { MS }\end{array}$ & $\begin{array}{l}\text { Yale University, } \\
\text { New Haven }\end{array}$ & $\begin{array}{l}\text { Performed multivariate statistical } \\
\text { analyses and modeling }\end{array}$ \\
\hline $\begin{array}{l}\text { Jessica S. } \\
\text { Alvey, MS }\end{array}$ & $\begin{array}{l}\text { University of } \\
\text { Utah, Salt Lake } \\
\text { City }\end{array}$ & $\begin{array}{l}\text { Coordinated biorepository } \\
\text { participant information }\end{array}$ \\
\hline $\begin{array}{l}\text { Lawrence J. } \\
\text { Cook, PhD }\end{array}$ & $\begin{array}{l}\text { University of } \\
\text { Utah, Salt Lake } \\
\text { City }\end{array}$ & $\begin{array}{l}\text { Managed biorepository participant } \\
\text { information }\end{array}$ \\
\hline $\begin{array}{l}\text { Terry J. Smith, } \\
\text { MD }\end{array}$ & $\begin{array}{l}\text { University of } \\
\text { Michigan, Ann } \\
\text { Arbor }\end{array}$ & $\begin{array}{l}\text { Designed and conceptualized the } \\
\text { study, interpreted data, and } \\
\text { revised the manuscript for } \\
\text { intellectual content }\end{array}$ \\
\hline $\begin{array}{l}\text { Michael R. } \\
\text { Yeaman, PhD }\end{array}$ & $\begin{array}{l}\text { University of } \\
\text { California, Los } \\
\text { Angeles }\end{array}$ & $\begin{array}{l}\text { Designed and conceptualized the } \\
\text { study, interpreted data, and } \\
\text { revised the manuscript for } \\
\text { intellectual content }\end{array}$ \\
\hline $\begin{array}{l}\text { Kevin C. } \\
\text { O'Connor, PhD }\end{array}$ & $\begin{array}{l}\text { Yale University, } \\
\text { New Haven }\end{array}$ & $\begin{array}{l}\text { Designed and conceptualized the } \\
\text { study, supervised data acquisition, } \\
\text { interpreted data, and revised the } \\
\text { manuscript for intellectual content }\end{array}$ \\
\hline
\end{tabular}

Appendix 2 Coinvestigators from the Guthy-Jackson Charitable Foundation CIRCLES Study Group

\begin{tabular}{lll}
\hline Name & Location & Contribution \\
\hline Lilyana & Department of Neurology, Keck & Reviewed and revised \\
Amezcua, & $\begin{array}{l}\text { School of Medicine, University } \\
\text { of Southern California, Los }\end{array}$ & $\begin{array}{l}\text { the manuscript for } \\
\text { intellectual content }\end{array}$ \\
& Angeles & \\
\hline
\end{tabular}

Continued 
Appendix 2 (continued)

\begin{tabular}{|c|c|c|}
\hline Name & Location & Contribution \\
\hline $\begin{array}{l}\text { Erika } \\
\text { Amundson, } \\
\text { BA }\end{array}$ & $\begin{array}{l}\text { Department of Neurology, Keck } \\
\text { School of Medicine, University } \\
\text { of Southern California, Los } \\
\text { Angeles }\end{array}$ & $\begin{array}{l}\text { Reviewed and revised } \\
\text { the manuscript for } \\
\text { intellectual content }\end{array}$ \\
\hline $\begin{array}{l}\text { Jeffrey L. } \\
\text { Bennett, } \\
\text { MD, PhD }\end{array}$ & $\begin{array}{l}\text { Departments of Neurology and } \\
\text { Ophthalmology, University of } \\
\text { Colorado School of Medicine, } \\
\text { Aurora }\end{array}$ & $\begin{array}{l}\text { Reviewed and revised } \\
\text { the manuscript for } \\
\text { intellectual content }\end{array}$ \\
\hline $\begin{array}{l}\text { Jacinta M. } \\
\text { Behne, MA }\end{array}$ & $\begin{array}{l}\text { The Guthy-Jackson Charitable } \\
\text { Foundation, Beverly Hills, CA }\end{array}$ & $\begin{array}{l}\text { Reviewed and revised } \\
\text { the manuscript for } \\
\text { intellectual content }\end{array}$ \\
\hline $\begin{array}{l}\text { Megan } \\
\text { Kenneally } \\
\text { Behne, AS }\end{array}$ & $\begin{array}{l}\text { The Guthy-Jackson Charitable } \\
\text { Foundation, Beverly Hills, CA }\end{array}$ & $\begin{array}{l}\text { Reviewed and revised } \\
\text { the manuscript for } \\
\text { intellectual content }\end{array}$ \\
\hline $\begin{array}{l}\text { Terrence M. } \\
\text { Blaschke, } \\
\text { MD, PhD }\end{array}$ & $\begin{array}{l}\text { Stanford University School of } \\
\text { Medicine. Palo Alto, CA }\end{array}$ & $\begin{array}{l}\text { Reviewed and revised } \\
\text { the manuscript for } \\
\text { intellectual content }\end{array}$ \\
\hline $\begin{array}{l}\text { Robert L. } \\
\text { Carruthers, } \\
\text { MD }\end{array}$ & $\begin{array}{l}\text { Department of Medicine \& } \\
\text { Neurology, University of British } \\
\text { Columbia, Vancouver, Canada }\end{array}$ & $\begin{array}{l}\text { Reviewed and revised } \\
\text { the manuscript for } \\
\text { intellectual content }\end{array}$ \\
\hline $\begin{array}{l}\text { Tanuja } \\
\text { Chitnis, MD }\end{array}$ & $\begin{array}{l}\text { Department of Neurology, } \\
\text { Brigham and Women's } \\
\text { Hospital, Harvard Medical } \\
\text { School, Boston, MA }\end{array}$ & $\begin{array}{l}\text { Reviewed and revised } \\
\text { the manuscript for } \\
\text { intellectual content }\end{array}$ \\
\hline
\end{tabular}

\begin{tabular}{lll}
\hline Jeffrey A. & Mellen Center for MS & $\begin{array}{l}\text { Reviewed and revised } \\
\text { the manuscript for }\end{array}$ \\
Cohen, MD & Treatment and Research, & intellectual content \\
& Neurological Institute, & \\
& Cleveland Clinic, OH &
\end{tabular}

\begin{tabular}{lll}
\hline Jessica & Department of Neurology, & $\begin{array}{l}\text { Reviewed and revised } \\
\text { Coleman, BA }\end{array}$ \\
& $\begin{array}{l}\text { Johns Hopkins University } \\
\text { School of Medicine, Baltimore, }\end{array}$ & intellectual content \\
& MD
\end{tabular}

\begin{tabular}{lll}
\hline Casey Engel, & Weill Cornell Medicine, New & Reviewed and \\
BA & York, NY & revised the \\
& & manuscript for \\
& intellectual \\
& content
\end{tabular}

\begin{tabular}{lll}
\hline $\begin{array}{l}\text { Lisa } \\
\text { Eunyoung } \\
\text { Lee, BS, MSc }\end{array}$ & $\begin{array}{l}\text { Department of Medicine \& } \\
\text { Neurology, University of } \\
\text { British Columbia, } \\
\text { Vancouver, Canada }\end{array}$ & $\begin{array}{l}\text { Reviewed and revised } \\
\text { the manuscript for } \\
\text { intellectual content }\end{array}$ \\
\hline $\begin{array}{l}\text { May H. Han, } \\
\text { MD }\end{array}$ & $\begin{array}{l}\text { Department of Neurology and } \\
\text { Neurological Sciences, Division } \\
\text { of Neuroimmunology and } \\
\text { Multiple Sclerosis Center, } \\
\text { Stanford University, CA }\end{array}$ & $\begin{array}{l}\text { Reviewed and revised } \\
\text { the manuscript for } \\
\text { intellectual content }\end{array}$ \\
\end{tabular}

\begin{tabular}{|c|c|c|}
\hline $\begin{array}{l}\text { Ruth } \\
\text { Johnson, BS }\end{array}$ & $\begin{array}{l}\text { Departments of Neurology } \\
\text { and Ophthalmology, } \\
\text { University of Colorado } \\
\text { School of Medicine, Aurora }\end{array}$ & $\begin{array}{l}\text { Reviewed and revised } \\
\text { the manuscript for } \\
\text { intellectual content }\end{array}$ \\
\hline $\begin{array}{l}\text { Diane } \\
\text { Ivancic, } \\
\text { CCRP }\end{array}$ & $\begin{array}{l}\text { Mellen Center for MS } \\
\text { Treatment and Research, } \\
\text { Neurological Institute, } \\
\text { Cleveland Clinic, OH }\end{array}$ & $\begin{array}{l}\text { Reviewed and revised } \\
\text { the manuscript for } \\
\text { intellectual content }\end{array}$ \\
\hline $\begin{array}{l}\text { Eric C. } \\
\text { Klawiter, MD }\end{array}$ & $\begin{array}{l}\text { Department of Neurology, } \\
\text { Massachusetts General } \\
\text { Hospital, Harvard Medical } \\
\text { School, Boston }\end{array}$ & $\begin{array}{l}\text { Reviewed and revised } \\
\text { the manuscript for } \\
\text { intellectual content }\end{array}$ \\
\hline $\begin{array}{l}\text { Alexandra } \\
\text { Kocsik, BS }\end{array}$ & $\begin{array}{l}\text { Weill Cornell Medicine, New } \\
\text { York, NY }\end{array}$ & $\begin{array}{l}\text { Reviewed and revised } \\
\text { the manuscript for } \\
\text { intellectual content }\end{array}$ \\
\hline
\end{tabular}

Appendix 2 (continued)

\begin{tabular}{|c|c|c|}
\hline Name & Location & Contribution \\
\hline $\begin{array}{l}\text { Mason } \\
\text { Kruse- } \\
\text { Hoyer, MD, } \\
\text { MA }\end{array}$ & $\begin{array}{l}\text { Weill Cornell Medicine, New } \\
\text { York, NY }\end{array}$ & $\begin{array}{l}\text { Reviewed and revised } \\
\text { the manuscript for } \\
\text { intellectual content }\end{array}$ \\
\hline $\begin{array}{l}\text { Michael } \\
\text { Levy, MD, } \\
\text { PhD }\end{array}$ & $\begin{array}{l}\text { Department of Neurology, } \\
\text { Massachusetts General } \\
\text { Hospital, Harvard Medical } \\
\text { School, Boston }\end{array}$ & $\begin{array}{l}\text { Reviewed and revised } \\
\text { the manuscript for } \\
\text { intellectual content }\end{array}$ \\
\hline $\begin{array}{l}\text { Libby Levine, } \\
\text { RN, ANP-BC }\end{array}$ & $\begin{array}{l}\text { Department of Neurology, } \\
\text { Columbia University Medical } \\
\text { Center, New York, NY }\end{array}$ & $\begin{array}{l}\text { Reviewed and revised } \\
\text { the manuscript for } \\
\text { intellectual content }\end{array}$ \\
\hline $\begin{array}{l}\text { Melanie } \\
\text { Marcille, BA }\end{array}$ & $\begin{array}{l}\text { Weill Cornell Medicine, New } \\
\text { York, NY }\end{array}$ & $\begin{array}{l}\text { Reviewed and revised } \\
\text { the manuscript for } \\
\text { intellectual content }\end{array}$ \\
\hline $\begin{array}{l}\text { Katrina } \\
\text { McMullen, } \\
\text { PhD }\end{array}$ & $\begin{array}{l}\text { Department of Medicine \& } \\
\text { Neurology, University of British } \\
\text { Columbia, Vancouver, Canada }\end{array}$ & $\begin{array}{l}\text { Reviewed and revised } \\
\text { the manuscript for } \\
\text { intellectual content }\end{array}$ \\
\hline $\begin{array}{l}\text { Maureen A. } \\
\text { Mealy, PhD }\end{array}$ & $\begin{array}{l}\text { Viela Bio, Gaithersburg, MD } \\
\text { (formerly Johns Hopkins } \\
\text { University School of Medicine, } \\
\text { Baltimore, MD) }\end{array}$ & $\begin{array}{l}\text { Reviewed and revised } \\
\text { the manuscript for } \\
\text { intellectual content }\end{array}$ \\
\hline $\begin{array}{l}\text { Stephanie } \\
\text { Moore, MPH }\end{array}$ & $\begin{array}{l}\text { Mellen Center for MS } \\
\text { Treatment and Research, } \\
\text { Neurological Institute, } \\
\text { Cleveland Clinic, OH }\end{array}$ & $\begin{array}{l}\text { Reviewed and revised } \\
\text { the manuscript for } \\
\text { intellectual content }\end{array}$ \\
\hline $\begin{array}{l}\text { Devin S. } \\
\text { Mullin, BS }\end{array}$ & $\begin{array}{l}\text { Department of Neurology, } \\
\text { Brigham and Women's } \\
\text { Hospital, Harvard Medical } \\
\text { School, Boston, MA }\end{array}$ & $\begin{array}{l}\text { Reviewed and revised } \\
\text { the manuscript for } \\
\text { intellectual content }\end{array}$ \\
\hline $\begin{array}{l}\text { Kaho B. } \\
\text { Onomichi, } \\
\text { MS }\end{array}$ & $\begin{array}{l}\text { Department of Neurology, } \\
\text { Columbia University Medical } \\
\text { Center, New York, NY }\end{array}$ & $\begin{array}{l}\text { Reviewed and revised } \\
\text { the manuscript for } \\
\text { intellectual content }\end{array}$ \\
\hline $\begin{array}{l}\text { Nancy M. } \\
\text { Nealon, MD }\end{array}$ & $\begin{array}{l}\text { Weill Cornell Medicine, New } \\
\text { York, NY }\end{array}$ & $\begin{array}{l}\text { Reviewed and revised } \\
\text { the manuscript for } \\
\text { intellectual content }\end{array}$ \\
\hline $\begin{array}{l}\text { Katherine E. } \\
\text { Nelson, BA }\end{array}$ & $\begin{array}{l}\text { Department of Neurology, } \\
\text { Columbia University Medical } \\
\text { Center, New York, NY }\end{array}$ & $\begin{array}{l}\text { Reviewed and revised } \\
\text { the manuscript for } \\
\text { intellectual content }\end{array}$ \\
\hline $\begin{array}{l}\text { Sarah M. } \\
\text { Planchon, } \\
\text { PhD }\end{array}$ & $\begin{array}{l}\text { Mellen Center for MS } \\
\text { Treatment and Research, } \\
\text { Neurological Institute, } \\
\text { Cleveland Clinic, OH }\end{array}$ & $\begin{array}{l}\text { Reviewed and revised } \\
\text { the manuscript for } \\
\text { intellectual content }\end{array}$ \\
\hline $\begin{array}{l}\text { Ana Pruitt, } \\
\text { BS }\end{array}$ & $\begin{array}{l}\text { Department of Neurology, Keck } \\
\text { School of Medicine, University } \\
\text { of Southern California, Los } \\
\text { Angeles }\end{array}$ & $\begin{array}{l}\text { Reviewed and revised } \\
\text { the manuscript for } \\
\text { intellectual content }\end{array}$ \\
\hline $\begin{array}{l}\text { Claire S. } \\
\text { Riley, MD }\end{array}$ & $\begin{array}{l}\text { Department of Neurology, } \\
\text { Columbia University Medical } \\
\text { Center, New York, NY }\end{array}$ & $\begin{array}{l}\text { Reviewed and revised } \\
\text { the manuscript for } \\
\text { intellectual content }\end{array}$ \\
\hline $\begin{array}{l}\text { Zoe Rimler, } \\
\text { BS }\end{array}$ & NYU Langone Health & $\begin{array}{l}\text { Reviewed and revised } \\
\text { the manuscript for } \\
\text { intellectual content }\end{array}$ \\
\hline $\begin{array}{l}\text { Andrew W. } \\
\text { Russo, BS }\end{array}$ & $\begin{array}{l}\text { Department of Neurology, } \\
\text { Massachusetts General } \\
\text { Hospital, Harvard Medical } \\
\text { School, Boston }\end{array}$ & $\begin{array}{l}\text { Reviewed and revised } \\
\text { the manuscript for } \\
\text { intellectual content }\end{array}$ \\
\hline $\begin{array}{l}\text { Julia J. } \\
\text { Schubert, BS, } \\
\text { BCS }\end{array}$ & $\begin{array}{l}\text { Department of Medicine \& } \\
\text { Neurology, University of } \\
\text { British Columbia, } \\
\text { Vancouver, Canada }\end{array}$ & $\begin{array}{l}\text { Reviewed and revised } \\
\text { the manuscript for } \\
\text { intellectual content }\end{array}$ \\
\hline
\end{tabular}


Appendix 2 (continued)

\begin{tabular}{lll}
\hline Name & Location & Contribution \\
\hline $\begin{array}{l}\text { Judy Sheard, } \\
\text { MPH, MA } \\
\text { CCRA }\end{array}$ & $\begin{array}{l}\text { The Guthy-Jackson Charitable } \\
\text { Foundation, Beverly Hills, CA }\end{array}$ & $\begin{array}{l}\text { Reviewed and revised } \\
\text { the manuscript for } \\
\text { intellectual content }\end{array}$ \\
\hline $\begin{array}{l}\text { Anna J. } \\
\text { Tomczak, MS }\end{array}$ & $\begin{array}{l}\text { Department of Neurology and } \\
\text { Neurological Sciences, Division } \\
\text { of Neuroimmunology and } \\
\text { Multiple Sclerosis Center, } \\
\text { Stanford University, CA }\end{array}$ & $\begin{array}{l}\text { Reviewed and revised } \\
\text { the manuscript for } \\
\text { intellectual content }\end{array}$ \\
\hline
\end{tabular}

\section{References}

1. Wingerchuk DM, Lennon VA, Lucchinetti CF, Pittock SJ, Weinshenker BG. The spectrum of neuromyelitis optica. Lancet Neurol 2007;6:805-815

2. Hinson SR, Lennon VA, Pittock SJ. Autoimmune AQP4 channelopathies and neuromyelitis optica spectrum disorders. Handb Clin Neurol 2016;133:377-403.

3. Lennon VA, Wingerchuk DM, Kryzer TJ, et al. A serum autoantibody marker of neuromyelitis optica: distinction from multiple sclerosis. Lancet 2004;364:2106-2112.

4. Lennon VA, Kryzer TJ, Pittock SJ, Verkman AS, Hinson SR. IgG marker of optic-spinal multiple sclerosis binds to the aquaporin-4 water channel. J Exp Med 2005;202:473-477.

5. Bennett JL, Lam C, Kalluri SR, et al. Intrathecal pathogenic anti-aquaporin-4 antibodies in early neuromyelitis optica. Ann Neurol 2009;66:617-629.

6. Asavapanumas N, Ratelade J, Papadopoulos MC, Bennett JL, Levin MH, Verkman AS. Experimental mouse model of optic neuritis with inflammatory demyelination produced by passive transfer of neuromyelitis optica-immunoglobulin G. J Neuroinflammation 2014;11:16.

7. Kinoshita M, Nakatsuji Y, Kimura T, et al. Neuromyelitis optica: passive transfer to rats by human immunoglobulin. Biochem Biophys Res Commun 2009;386:623-627.

8. Weinshenker BG, Wingerchuk DM. Neuromyelitis spectrum disorders. Mayo Clin Proc 2017;92:663-679.

9. Saadoun S, Waters P, Bell BA, Vincent A, Verkman AS, Papadopoulos MC. Intracerebral injection of neuromyelitis optica immunoglobulin $\mathrm{G}$ and human complement produces neuromyelitis optica lesions in mice. Brain 2010;133:349-361.

10. Hinson SR, Romero MF, Popescu BF, et al. Molecular outcomes of neuromyelitis optica (NMO)-IgG binding to aquaporin-4 in astrocytes. Proc Natl Acad Sci USA 2012;109:1245-1250.

11. Kitley J, Woodhall M, Waters $\mathrm{P}$, et al. Myelin-oligodendrocyte glycoprotein antibodies in adults with a neuromyelitis optica phenotype. Neurology 2012;79:1273-1277.

12. Hamid SHM, Whittam D, Mutch K, et al. What proportion of AQP4-IgG-negative NMO spectrum disorder patients are MOG-IgG positive? A cross sectional study of 132 patients. J Neurol 2017;264:2088-2094.

13. Sato DK, Callegaro D, Lana-Peixoto MA, et al. Distinction between MOG antibody-positive and AQP4 antibody-positive NMO spectrum disorders. Neurology 2014;82:474-481.

14. Wingerchuk DM, Banwell B, Bennett JL, et al. International consensus diagnostic criteria for neuromyelitis optica spectrum disorders. Neurology 2015;85:177-189.

15. Takahashi T, Fujihara K, Nakashima I, et al. Anti-aquaporin-4 antibody is involved in the pathogenesis of NMO: a study on antibody titre. Brain 2007;130:1235-1243.

16. Matiello M, Lennon VA, Jacob A, et al. NMO-IgG predicts the outcome of recurrent optic neuritis. Neurology 2008;70:2197-2200.

17. Kang H, Chen T, Li H, Xu Q, Cao S, Wei S. Prognostic factors and disease course in aquaporin- 4 antibody-positive Chinese patients with acute optic neuritis. J Neurol $2017 ; 264: 2130-2140$
18. Pellkofer HL, Krumbholz M, Berthele A, et al. Long-term follow-up of patients with neuromyelitis optica after repeated therapy with rituximab. Neurology 2011;76: $1310-1315$.

19. Cook LJ, Rose JW, Alvey JS, et al. Collaborative International Research in Clinical and Longitudinal Experience Study in NMOSD. Neurol Neuroimmunol Neuroinflamm 2019;6:e583.

20. Finak G, Langweiler M, Jaimes M, et al. Standardizing flow cytometry immunophenotyping analysis from the Human ImmunoPhenotyping Consortium. Sci Rep 2016;6:20686.

21. Ding J, Zhu DS, Hong RH, et al. The differential expression of natural killer cells in NMOSD and MS. J Clin Neurosci 2020;71:9-14.

22. Ratelade J, Asavapanumas N, Ritchie AM, Wemlinger S, Bennett JL, Verkman AS. Involvement of antibody-dependent cell-mediated cytotoxicity in inflammatory demyelination in a mouse model of neuromyelitis optica. Acta Neuropathol 2013;126:699-709.

23. Lanier LL, Le AM, Civin CI, Loken MR, Phillips JH. The relationship of CD16 (Leu11) and Leu-19 (NKH-1) antigen expression on human peripheral blood NK cells and cytotoxic T lymphocytes. J Immunol 1986;136:4480-4486.

24. Saadoun S, Bridges LR, Verkman AS, Papadopoulos MC. Paucity of natural killer and cytotoxic T cells in human neuromyelitis optica lesions. Neuroreport 2012;23:1044-1047.

25. Ratelade J, Zhang H, Saadoun S, Bennett JL, Papadopoulos MC, Verkman AS. Neuromyelitis optica IgG and natural killer cells produce NMO lesions in mice without myelin loss. Acta Neuropathol 2012;123:861-872.

26. Vincent T, Saikali P, Cayrol R, et al. Functional consequences of neuromyelitis opticaIgG astrocyte interactions on blood-brain barrier permeability and granulocyte recruitment. J Immunol 2008;181:5730-5737.

27. Rodriguez-Martin E, Picon C, Costa-Frossard L, et al. Natural killer cell subsets in cerebrospinal fluid of patients with multiple sclerosis. Clin Exp Immunol 2015;180: 243-249.

28. Zhang B, Yamamura T, Kondo T, Fujiwara M, Tabira T. Regulation of experimental autoimmune encephalomyelitis by natural killer (NK) cells. J Exp Med 1997;186: 1677-1687.

29. Hatori K, Nagai A, Heisel R, Ryu JK, Kim SU. Fractalkine and fractalkine receptors in human neurons and glial cells. J Neurosci Res 2002;69:418-426.

30. Pan Y, Lloyd C, Zhou H, et al. Neurotactin, a membrane-anchored chemokine upregulated in brain inflammation. Nature 1997;387:611-617.

31. Kastenbauer S, Koedel U, Wick M, Kieseier BC, Hartung HP, Pfister HW. CSF and serum levels of soluble fractalkine (CX3CL1) in inflammatory diseases of the nervous system. J Neuroimmunol 2003;137:210-217.

32. Imai T, Hieshima $\mathrm{K}$, Haskell $\mathrm{C}$, et al. Identification and molecular characterization of fractalkine receptor CX3CR1, which mediates both leukocyte migration and adhesion. Cell 1997;91:521-530.

33. Campbell JJ, Qin S, Unutmaz D, et al. Unique subpopulations of CD56+ NK and NK$\mathrm{T}$ peripheral blood lymphocytes identified by chemokine receptor expression rep ertoire. J Immunol 2001;166:6477-6482.

34. Tuo J, Smith BC, Bojanowski CM, et al. The involvement of sequence variation and expression of CX3CR1 in the pathogenesis of age-related macular degeneration. FASEB J 2004;18:1297-1299.

35. Okada K, Matsushita T, Kira J, Tsuji S. B-cell activating factor of the TNF family is upregulated in neuromyelitis optica. Neurology 2010;74:177-178.

36. Wang H, Wang K, Zhong X, et al. Cerebrospinal fluid BAFF and APRIL levels in neuromyelitis optica and multiple sclerosis patients during relapse. J Clin Immunol 2012;32:1007-1011.

37. Lesley $\mathrm{R}, \mathrm{Xu}$ Y, Kalled SL, et al. Reduced competitiveness of autoantigen-engaged $B$ cells due to increased dependence on BAFF. Immunity 2004;20:441-453.

38. Groom J, Kalled SL, Cutler AH, et al. Association of BAFF/BLyS overexpression and altered B cell differentiation with Sjogren's syndrome. J Clin Invest 2002;109:59-68.

39. Pers JO, Daridon C, Devauchelle V, et al. BAFF overexpression is associated with autoantibody production in autoimmune diseases. Ann NY Acad Sci 2005;1050:34-39.

40. Schuh E, Berer K, Mulazzani M, et al. Features of human CD3+CD20+ T cells. J Immunol 2016;197:1111-1117. 


\section{Neurology \\ Neuroimmunology \& Neuroinflammation}

\section{High-throughput investigation of molecular and cellular biomarkers in NMOSD}

Soumya S. Yandamuri, Ruoyi Jiang, Aditi Sharma, et al.

Neurol Neuroimmunol Neuroinflamm 2020;7;

DOI 10.1212/NXI.0000000000000852

This information is current as of August 4, 2020

Updated Information \&

Services

References

Subspecialty Collections

Permissions \& Licensing

Reprints including high resolution figures, can be found at:

http://nn.neurology.org/content/7/5/e852.full.html

This article cites 40 articles, 8 of which you can access for free at: http://nn.neurology.org/content/7/5/e852.full.html\#\#ref-list-1

This article, along with others on similar topics, appears in the following collection(s):

Autoimmune diseases

http://nn.neurology.org//cgi/collection/autoimmune_diseases

Information about reproducing this article in parts (figures,tables) or in its entirety can be found online at:

http://nn.neurology.org/misc/about.xhtml\#permissions

Information about ordering reprints can be found online: http://nn.neurology.org/misc/addir.xhtml\#reprintsus

Neurol Neuroimmunol Neuroinflamm is an official journal of the American Academy of Neurology.

Published since April 2014, it is an open-access, online-only, continuous publication journal. Copyright

Copyright $(\subseteq 2020$ The Author(s). Published by Wolters Kluwer Health, Inc. on behalf of the American

Academy of Neurology.. All rights reserved. Online ISSN: 2332-7812.

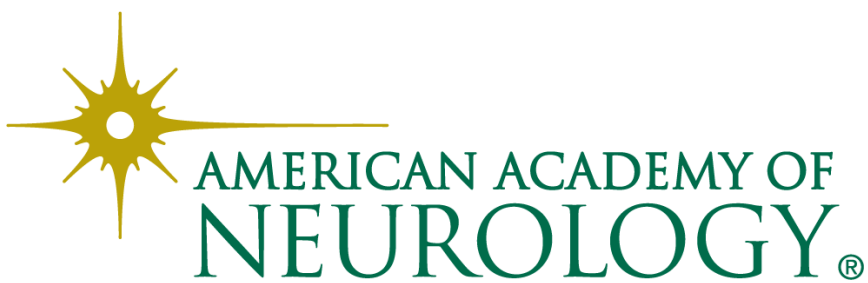

